\title{
Influenza pandemics: past, present and future challenges
}

\author{
Antoine Flahault MD, $\mathrm{PhD},{ }^{1}$ \\ Patrick Zylberman $\mathrm{PhD}^{2}$
}

\begin{abstract}
Influenza epidemics occur regularly and prediction of their conversion to pandemics and their impact is difficult. Coordination of efforts on a global scale to control or reduce the impact is fraught with potential for under and overreaction. In light of the 1956 pandemic and more recently the SARS and H1N1 pandemics, the public health community took steps toward strengthening global surveillance and a coordinated response in keeping with the continuing memory of the tragedy seen in 1918. The scientific, professional, and technical resources of the $21^{\text {st }}$ century are now advanced far beyond those then available. The H1N1 pandemic which commenced in 2009 progressed differently than predicted; its course was difficult to predict with any degree of certainty. Public responses to national immunization programs against the $\mathrm{H} 1 \mathrm{~N} 1$ virus have been weak. International movement of diseases can lead to creation of new endemic areas and continuous spread such as that which happened with West Nile Fever and Chikungunya. The lessons learned and the public and political responses to each actual or threatened pandemic will serve public health well in dealing with future challenges.
\end{abstract}

Key Words: influenza A (H1N1), influenza policy, global influenza monitoring, pandemic 1918, 1976, vaccination, SARS, antivirals

\section{INTRODUCTION}

The first influenza pandemic of the $21^{\text {st }}$ century which started in May of 2009 and swept through the Northern Hemisphere in two waves, receding after the autumn of 2009 , but still circulating widely, made its mark on the history of epidemics. ${ }^{1}$ This pandemic threat again raised global concerns stemming from memories of previous pandemics, principally the 1918 "Swine Flu" which killed many tens of millions of people., ${ }^{2,3}$

\footnotetext{
${ }^{1}$ Antoine Flahault, Dean, EHESP School of Public Health.

${ }^{2}$ Patrick Zylberman, Professor, History of Health. EHESP School of Public Health.
}

Correspondence: Antoine Flahault at email Antoine.Flahault@ehesp.fr 
Influenza A (H1N1) is the first for which a worldwide response was prepared in a coordinated, planned and organised fashion. Some countries reacted to the threat of Swine Flu in 1976, and prepared massive immunization programs in anticipation of a 1918 type pandemic, but the disease did not spread and political and public confidence in the public health agencies was reduced. ${ }^{4}$

For many other emerging large outbreaks (e.g., influenza, AIDS, SARS, dengue fever or Chikungunya) during the $20^{\text {th }}$ century, there was little or no advanced preparation. SARS was an example of a potential pandemic for which the scientific community and international public health efforts were poorly prepared. It was not until the last wave of the epidemic, in May 2003, that the first scientific articles on SARS were published ${ }^{5,6}$ However, for influenza A (H1N1), in May 2009, less than one month after the initial cases presented in the Mexican alert, nearly all the international media as well as medical and scientific reviews were publishing a flood of articles throwing light, sometimes contradictory but always useful, on decisionmaking at the local, regional and international levels.

Preparations had been made on a global scale for the emergence of a pandemic influenza of the $\mathrm{A}(\mathrm{H} 5 \mathrm{~N} 1)$ avian influenza virus that was rampant mainly in Southeast Asia in 2006-2007. This virulent strain was much feared owing to its rare but dreaded transmission from infected birds to man, and high mortality rate (59 percent), with 262 deaths out of 442 reported cases (cumulative cases from 2003 to September 2009). ${ }^{7}$

A new influenza A (H1N1) strain emerged from North America, in late April 2009, identified subsequently as a potential pandemic. More than eight months after it was identified, it was still not known, even very roughly, how many people had been affected throughout the world. As many countries have stopped counting cases, the proportion of mild or asymptomatic cases remained unknown. Most developed countries have taken precautions that seem disproportionate in light of the experience in the Southern Hemisphere during the Austral winter (June-September 2009). ${ }^{8}$ Nearly everywhere, vaccination priorities were in turmoil. The politicians' and manufacturers' race against time to produce vaccines seemed to have been won by October of 2009. The first batches were available in the Northern Hemisphere by the start of the autumn-winter wave. This wave came earlier than the regular seasonal influenza. Industrialised countries, in which extensive preparation was undertaken for this pandemic, were, therefore, well-prepared, whereas the needs of the developing countries were not being addressed. 
THE START OF THE H1N1 PANDEMIC IN APRIL 2009 IN THE AMERICAS

A new strain of the influenza A (H1N1) virus was first identified in April 2009 and was soon considered to have pandemic potential. Although a significant proportion of people over age 50 showed a residual immunity, nobody knew whether they would really be protected. The age distribution of $\mathrm{H} 1 \mathrm{~N} 1$ pandemic cases in the United States population was very similar to that for seasonal $\mathrm{H} 1 \mathrm{~N} 1$ influenza recorded over recent years. ${ }^{9}$ Incidence was highest in the 5-24 age group, followed by the $0-4$, and then by the 25-49 and lowest among the mature adults and elderly. ${ }^{10}$ The wave was fairly moderate in size but with unusually higher mortality among children and young adults than during seasonal influenza outbreaks. ${ }^{11}$ Among the very elderly, the mortality was lower than that expected from seasonal influenza.

At the end of the spring and during the summer of 2009, North America experienced an unusually high number of influenza cases for the season. The virus was then projected into all countries by infected air travellers. Fear was raised concerning serious economic consequences for tourism, international trade and the possibility of a blockade on air travel for health reasons. Reassuring reports on the lack of severity in the great majority of cases of infection caused by this virus quickly avoided the suspension of flights. During the austral winter of 2009, the clinical attack rate (percentage of people suffering from influenza symptoms) did not appear to have exceeded 10 to 15 percent in the Southern Hemisphere. However, there are very few data on asymptomatic or mildly symptomatic infections in these areas of the world. ${ }^{12}$ In cases where the number of deaths and number of cases are known with reasonable precision (New Caledonia, La Réunion, Mauritius and New York), ${ }^{13}$ the mortality directly attributable to the H1N1pdm virus was roughly estimated at about 1 in 10,000 clinical cases. Death was usually caused by viral pneumonia leading to acute respiratory distress syndrome (ARDS) which is a very rare occurrence with seasonal influenza (probably less than one death in a million cases). ${ }^{13}$

According to the Centers for Disease Control and Prevention (CDC), nearly one third of deaths were found to have had an invasive bacterial co-infection mostly caused by pneumococcus. ${ }^{14}$ In a series of 722 patients hospitalised in intensive care units in Australia and New Zealand with confirmed H1N1pdm, 20 percent had bacterial superinfections. ${ }^{15}$ However, indirect mortality, usually recorded by death statistics, had not yet been estimated in most parts of the world, although a few countries such as the US reported mortality rates above the threshold from October of 2009, 
through surveillance of pneumonia and influenza mortality. ${ }^{16}$ During seasonal influenza, less than 10 percent of this indirect excess mortality which is statistically estimated is usually identified by clinicians and reported in death certificates.

In May of 2009, the WHO announced that there had been 30,000 confirmed cases of $\mathrm{H} 1 \mathrm{~N} 1$ pandemic influenza, but the same day, the CDC estimated around a million cases. ${ }^{17,18}$ In October of 2009, the CDC's estimation of the total number of cases in the US was between 14 and 22 million, with 63-153 thousand hospitalizations and 2,500 to 6,000 deaths, underscoring the very imprecise methods of estimation. ${ }^{19}$ These are huge discrepancies which are well known in the world of official statistics. This example is given because the numbers come from what is considered to be the most authoritative epidemiologic surveillance body. Everyone is in a state of confusion. In France, as in other countries, the "sentinel" doctors do not have the means to confirm the virology of the suspected clinical cases that they report via Internet. ${ }^{20}$ As for developing countries, how can those who, for example, do not have official records of births and deaths identify the causes of mortality, let alone estimate morbidity during such an epidemic?

\section{9-2009: THE LONG GAP BETWEEN PANDEMICS}

There has been a long gap between influenza pandemics during the past forty years. The Sentinelles network set up in November of 1984 by Epidemiology Centre for Causes of Death (INSERM) and Pierre et Marie Curie University, with the support of the Director of Health at the French Ministry of Health and the French Institute for Public Health Surveillance, monitors, detects and forecasts (over a three week period) changes in the course of winter influenza outbreaks. Every year, between November and March, a unimodal influenza epidemic wave sweeps through the whole of France. On average, three million clinical cases are examined by general practitioners, of about six million infections overall. ${ }^{21,22}$ These seasonal influenza outbreaks are closely synchronized on both sides of the Atlantic. There is less than a week's delay between the peak mortality attributed to influenza and pneumonia in France and in the US. ${ }^{23}$

Since 1977, seasonal influenza has seen the co-circulation of the A (H3N2) subtype which emerged in 1968 in Hong Kong, the A (H1N1) subtype which re-emerged in 1977 from the former USSR, and Influenza B. Seasonal influenza primarily affects young people (median age around 25 years old) but mainly kills the elderly (90 percent of deaths in those above 75 years old). However, as mentioned above, it is estimated that 
deaths attributable to influenza (primary or secondary cause) account for less than 10 percent of excess mortality recorded in developed countries. In France, 600 deaths on average are recorded each year by the INSERM, but excess mortality related to influenza is estimated at 6,000, with the young being affected most, both in France and in the US, as compared to the predominance of elderly deaths in the usual seasonal influenza. ${ }^{24}$

A similar order of magnitude is given by US mortality data, from which a total of 36,000 average annual excess deaths is estimated. ${ }^{25,26}$ Taking direct and indirect causes together, excess mortality caused by seasonal influenza in rich countries is around one in 1,000 infections. ${ }^{27}$

The fairly rapidly ageing population in these countries probably accounted for a slight increase in these figures during the 2000s. The new antiviral drugs that have been put on the market as preventive or curative measures (oseltamivir and zanamivir) have not yet proved to be a fully satisfactory remedy against seasonal influenza. Very little research is being carried out to try to gain a better understanding of how the virus spreads, in particular by ways other than airborne infection. In developed countries, preventive measures are focused on vaccinating persons at risk: elderly persons over 65 and people suffering from certain long-term conditions for whom vaccination is recommended.

No country has attempted to prevent the onset of these winter epidemics using a mass immunization strategy. In Japan, vaccination of children was recommended in the 1970s-1980s until it was stopped without rigorous evaluation, despite good arguments that it could be worthwhile. ${ }^{28} \mathrm{CDC}$ recommends annual immunization of children from 6 months to 19 years of age along with pregnant women and people over age 50, people with chronic illnesses, health care workers, people in chronic care facilities and other risk groups with seasonal flu vaccine..$^{29}$ Between 1969 and 2009, during the long period between pandemics, health systems coped, without undue problems, with seasonal outbreaks of influenza (as well as gastroenteritis) that most winters placed strain on the health services, and brought about excess direct medico-economic costs and indirect costs in terms of sick leave and loss of productivity. 


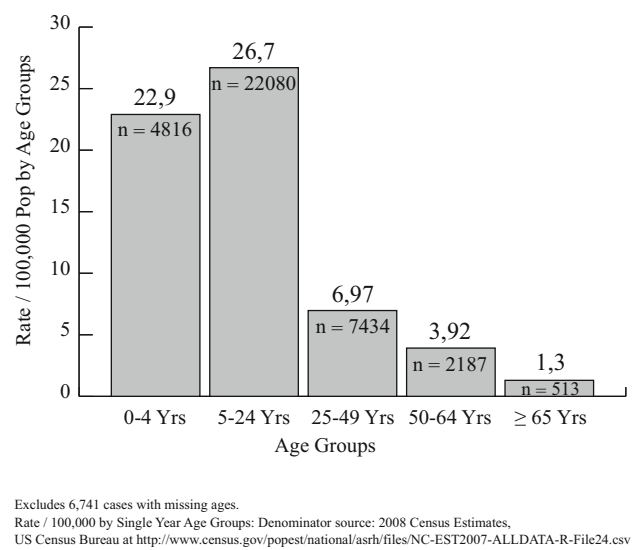

Fig. 1. Novel H1N1 Confirmed and Probable Case Rate in the United States, 2009, by Age Group.

Source: CDC $^{10} 2009$ H1N1 Early outbreak and disease characteristics Available from : http://www. cdc.gov/H1N1FLU/surveillanceqa.htm

\section{8-1919: THE QUINTESSENTIAL IMAGE OF A PANDEMIC}

Since the bird flu scare in 2004, there has been considerable speculation about the severity of a future influenza pandemic which, it is said, could be just as deadly as the 1918-1919 influenza pandemic. SARS (severe acute respiratory syndrome) had already struck in 2003 like a "dress rehearsal", with 8,096 cases detected in 26 countries and 774 deaths. ${ }^{30}$ Is such a comparison justified? It assumes that certain major questions still pending have been resolved. What micro-organism caused the 1918 pandemic? Sequencing the virus in 2005 provides an answer, but only for the autumn 1918 wave. The samples used by geneticists all came from patients who died in September 1918. The virus responsible for the influenza symptoms arising in spring and summer of 1918 has not yet been identified. Furthermore, sequencing does not reveal anything about the geographic origin of the virus. ${ }^{31,32}$ Did it come from China, ${ }^{33}$ the US or Europe? $2,34,35$ Was it a "new" disease in 1918 ? Why was it so virulent (Table 1)? ${ }^{36}$ Why was mortality so high among young adults?

The A (H1N1) "Spanish" influenza epidemic, the first influenza pandemic of the $20^{\text {th }}$ century, wrought havoc on the world population between MayJune of 1918 and April of 1919. It killed at least 50 million people, five times as many as those who died fighting in the First World War. Many deaths were the result of secondary bacterial infections (pneumonia, 
bronchopneumonia) that were particularly serious in those suffering from pulmonary pathology (tuberculous patients). ${ }^{37,38}$ More than 600,000 people died in the US directly or indirectly because of the epidemic. The excess mortality was about 260,000 in France, nearly 220,000 in Great Britain and an equivalent number in Germany during the deadly wave in autumn 1918. Average mortality was nearly 2.5 percent in the US and 4 percent in Europe. Some "naïve" populations such as the Western Samoans (then controlled by New Zealand) suffered terrible mortality ( 22 percent ). ${ }^{2,39}$,

Table 1

Mortality during the three influenza pandemics of the $20^{\text {th }}$ century in the United States

\begin{tabular}{c|c|c}
\cline { 2 - 3 } & $\begin{array}{c}\text { Excess mortality during the } \\
\text { pandemic season (all causes) }\end{array}$ & $\begin{array}{c}\text { Excess mortality: gross for } \\
100,000 \text { inhabitants (all } \\
\text { causes) }\end{array}$ \\
\hline $1918-1919 \mathrm{~A}(\mathrm{H} 1 \mathrm{~N} 1)$ & $\sim 500,000$ & 530 \\
\hline $1957-1958 \mathrm{~A}(\mathrm{H} 2 \mathrm{~N} 2)$ & $\sim 60,000$ & 40 \\
\hline $1968-1969 \mathrm{~A}(\mathrm{H} 3 \mathrm{~N} 2)$ & $\sim 40,000$ & 18 \\
\hline
\end{tabular}

Source: Yin S. ${ }^{36}$ Avian flu and influenza pandemics. Washington: Population Reference Bureau; 2006. 11 January, 2006.

The characteristics of the pandemic are well known: mortality rate 5 to 20 times higher than expected, high proportion of complications, unusually high mortality in the 15-39 year old age group, three successive waves within 8 to 9 months, the only influenza outbreak of its kind on record. ${ }^{31,40}$ It is sometimes said that these influenza characteristics were unknown at the time. ${ }^{39}$ In France, however, in 1919, the Préfecture de la Seine started publishing statistics on the epidemic in Paris and the War Ministry followed suit in 1922. ${ }^{41-43}$ Apart from the virology aspects (the virus was not identified in pigs until 1931 and in man until 1933) and despite reservations about the accuracy of the statistics at the time, the descriptive epidemiology of "Spanish" flu was determined almost immediately.

Most historians now attribute the speed of infection to the significant increase in maritime and rail transport related to the world war. However, the phenomenon was not new. An influenza pandemic had swept Europe from December of 1781 to August of 1782. Although mortality was low (mainly the elderly), the attack rate was very high: three quarters of the population of Europe may have been affected. The virus is thought to have come from Central Asia and it took eight months to travel the 5,000 
kilometres that separate the Urals from Portugal. ${ }^{44}$ Its journey was greatly assisted by the use of rivers and seas (the Baltic and Mediterranean) for transport and trade, much more so than by the difficult, slower land routes (across the Alps and Pyrenees).

The emergence of a new virus was, therefore, associated with the expansion of transport due to "globalisation" in the $18^{\text {th }}$ century, or rather "Europeanisation". When he founded Saint Petersburg in 1703, Peter the Great wanted the city to open "a window on Europe", which turned out to be only too true in 1781 . The connection has only recently been made. The idea of the contagious nature of influenza first had to be accepted. In 1781-1782, the scientists of the Enlightenment, who set great store by meteorological and climatic explanations, were at first disconcerted by the way the epidemic moved east to west, in the opposite direction from the prevailing winds. Suspicions arose that influenza might be contagious and then, in 1889-1890, the propagation of the virus along land and maritime routes convinced contemporaries that influenza was indeed contagious. ${ }^{44,45}$

Today, this is the quintessential image of the epidemic: a health crisis as well as a socioeconomic crisis, causing massive destruction and massive disorganisation. It is a persistent topic in literature: Lucretius, Boccaccio, Defoe, as well as nearer-to-home Artaud, Giono, Camus and many others have drawn on Thucydides and his famous description of the plague of Athens (possibly smallpox, an infectious respiratory disease). ${ }^{46}$ An epidemic not only results in suffering caused by the propagation of an infection, but also in the disintegration of power, social structures and customs which ensues: "human society in extremis" ${ }^{47}$ The Thucydides' paradigm, whether it is real or imaginary, forms the basis for all current anti-pandemic plans.

\section{7-1958 AND 1968-1970: TOO LITTLE TOO LATE}

The 1957-1958 pandemic has been called the first pandemic of the era of modern virology, ${ }^{48}$ and when the A (H3N2) subtype emerged in 1968-1969 causing the third pandemic of the $20^{\text {th }}$ century, virology was a well established discipline. Antiviral drugs were mass produced (amantadine and rimantadine, since abandoned as viruses became resistant and rare, and from which severe undesirable neurological side effects occurred) and there were modern intensive care facilities, at least in developed countries.

The Hong Kong 1968-1970 influenza pandemic passed almost unnoticed, even though it spread worldwide in less than two years given the already significant increase in intercontinental travel. ${ }^{49,50}$ Hong Kong was the hub of air travel to the whole of Asia. The attack rate conformed to the models 
drawn up in the 1980s (40-50 percent with slightly under half being mild or asymptomatic cases) and a mortality rate of 2 to 4 in one thousand. Excess mortality in France stood at 30,000 deaths (five times higher than the rate for seasonal influenza), deaths that then passed unnoticed; they were identified retrospectively in a review of the surge of mortality data for the heat wave in August of 2003, which caused the premature death of 15,000 vulnerable elderly persons ${ }^{51}$ Retrospective analysis reveals infection rates five to six times greater than that for seasonal influenza but with moderate virulence. $\mathrm{H} 3 \mathrm{~N} 2$ has replaced $\mathrm{H} 2 \mathrm{~N} 2$ which has not been identified in France since January of 1969 , at the start of the pandemic wave.

In 1968, as in 1957, annual vaccination against seasonal influenza was well established. Technical problems (inadequate monitoring, limited production capacity, inadequate clinical test methodology, still unexplored strategies for reducing antigen doses) and legal problems (safety standards) prevented vaccination from being fully available in developed countries. Government action foundered on the logistics and organisation of the campaign. In the US, in 1968 as well as 1957, "too little vaccine was administered too late." ${ }^{2}$ In 1957, 49 million doses were available in the US at the peak of the epidemic: only half were used. In 1968-1969, only 15 million doses were delivered at the peak of the epidemic. The health services proved unable to organise themselves in time. Most of these obstacles have now been overcome. The problems are now "political and economic" and involve either reduction of the time necessary for putting products on the market or equity in distributing doses. ${ }^{53}$ In December of 2009, social issues surrounding vaccine were also at the height of public attention in France, including popular reluctance to mass immunization, widespread fear of adverse effects of the vaccine, and circulation of rumours on the Internet, including that of a "vast conspiracy" attributed to various sources..$^{54,55}$

\section{6: THE EPIDEMIC THAT NEVER WAS}

The advent of the Asian flu in 1957-1958 recalled the events of the 1918 influenza pandemic to professional and public attention, appearing as the quintessential image of modern pandemics. Subsequent anti-pandemic scenarios were largely based on the "1918-like" scenario. Not knowing what new measures to take when confronted by the originality of unexpected situations, we draw on what Paul Valéry called our "imaginary memories". ${ }^{56}$ This reflects the reaction of the US government to the outbreak of "swine flu" at the Fort Dix base of the U.S. Army in New Jersey. 
Between January $19^{\text {th }}$ and February $9^{\text {th }}, 1976,230$ new recruits between 17 and 21 years old showed signs of respiratory infection. Thirteen were admitted to the hospital. On February $4^{\text {th }}$, one of the patients died (viral pneumonia). The outbreak fizzled out in February, but the virus was identified as the same A (H1N1) subtype as the Spanish influenza virus which had not been around since $1920 .{ }^{57}$ Experts became increasingly concerned about the co-circulation of the two subtypes, A H1N1 and A H3N2. A H3N2 had been dominant since 1968, but would it be able to form a barrier against H1N1? Was there a risk of the two viruses merging? ${ }^{48}$ Current sources tend to convey a conflicting picture of the learned opinions at the time. According to Richard Krause, then Director of the National Institute for Allergies and Infectious Diseases (NIAID), in February, experts from the CDC, NIAID and Merck agreed that there was a risk of a pandemic "perhaps similar to the pandemic of 1918".

There was considerable alarm. ${ }^{58}$ Yet, in his memorandum addressed to the White House, Dr David Sencer, Director of the CDC, "specifically underemphasized the specter of the 1918 pandemic" ${ }^{59}$ but nonetheless underscored a "strong possibility" for a pandemic "antigenically related" to $1918 .{ }^{60}$ On the other hand, Dr Walter Dowdle, chief of the virology section at $\mathrm{CDC}$ at the time the $\mathrm{A} / \mathrm{New}$ Jersey/1976 subtype was isolated, claims that, on the $10^{\text {th }}$ of March, 1976, "the Army provided data to the US Advisory Committee on Immunization Practices that confirmed person-to-person transmission of swine influenza virus. The single death from swine flu loomed large, although most cases were mild. No one at the advisory committee meeting equated the disease potential of this [1976] virus with 1918."'61

What measures should the country take in the absence of tangible signs of an imminent epidemic? Experts had difficulty in quantifying a vague possibility. The press and Congress toyed with the image of the Spanish flu and its horrors like a poisonous prophecy. Dr Theodore Cooper, Assistant Secretary for Health, made the connection between swine flu and 1918 in a note addressed to the White House. Basing himself on a fashionable theory, he wrote that severe epidemics or influenza epidemics occur approximately every 10 years. In parallel, he sent President Gerald Ford a copy of Epidemic and Peace, 1918, by Alfred Crosby - one of the first books, if not the first, to describe Spanish flu from a historical point of view - that was published at the time when the first cases occurred. ${ }^{62}$ Cooper's father, himself a doctor, had told him about certain painful reminiscences such as soldiers burying flu victims en masse in Pennsylvania where he grew up. Events which might possibly happen suddenly became a real threat based on past events, which he remembered vividly. True-to-life, memories were regarded as a 
sound basis for predicting the future. Calculating probabilities was never part of the decision to launch a preventive mass vaccination campaign in 1976. "Expertise counts for a lot," wrote the two historians of swine flu, "but only by way of informing subjective judgement." In their view, the subjective probability (the image of 1918) would "in any case" have won the day. ${ }^{60}$

The vaccination programme was launched in October but stopped suddenly in December after 532 cases of Guillain-Barré syndrome occurred ( 25 deaths). The programme covered nearly 25 percent ( 45 million) of the US population. The epidemic petered out, but criticism was virulent. "The CDC lost its innocence", it was said, and with it, its influence. ${ }^{60}$ It would experience great difficulty in recovering. Public opinion and the scientific community accused it of having overreacted for sordidly political reasons. ${ }^{59}$ In the Presidential elections in November, Gerald Ford was defeated and Jimmy Carter became the new President. Was it a desperate attempt by Ford to re-establish his authority before the elections by a spectacular operation? It was said that only two aspects of this episode had anything to do with science: the identification of the A-subtype swine flu in February and the confirmation that an increased risk of Guillain-Barré syndrome was associated with the vaccination. Apart from this, "everything else was political". ${ }^{63}$ The 1976 influenza outbreak is, therefore, the first politicised historical pandemic, "the first time [the government] had been blamed for an epidemic that did not take place" ${ }^{58}$ The US strongly encouraged Canada to adopt the immunization for swine flu as well, but Canadian authorities deemed it better to wait and see if the epidemic spread out of Fort Dix, and just then all immunization was called off when the series of complications of the immunization began to appear in the US. ${ }^{64}$

\section{WHAT ABOUT THE NEXT ONE?}

Can the management of a predicted risk be planned given the scientific uncertainties described above, in particular relating to morbidity and mortality estimates? Much depends on the current pandemic: either the health system infrastructures hold, before, during and after the event, thanks to the efforts made, or they give way in places because the pandemic has medical consequences that are greater than predicted or because its impact on the socioeconomic organisation is more severe, undermining people's confidence. Governments will, in any case, wish to at least conserve a high level of vigilance by setting up measures for preparedness, 
and if possible, to be even better prepared for the next crisis which could be just as dangerous for the people as for the economy.

Scientists will also have great scope for new discoveries that they will not fail to exploit. The latest pandemic could well transform the "science of influenza". It could give us a better understanding of the mechanisms leading to mutations and recombinations of influenza viruses and it could provide real experience of effective barrier measures - in particular vaccination against seasonal epidemics, measures that could be implemented if the epidemic recurs and which would allow us to stop a strain with pandemic potential at the source. Rapid diagnostic tests would then be available in the future to identify the viral subtype.

Interdisciplinary observatories using the most up-to-date information could be set up in several places throughout the world, not only in developed countries. These "telescopes observing life", would be able to detect epidemics and epizootics. They would provide precise information almost in real time on seroprevalence rates, on virulence indicators, on the diversity of viruses circulating, and on the distribution of risk factors within the population, including those based on known genetic polymorphisms, not to mention on the state of perception, beliefs, attitudes and behaviour of people exposed to the risk of epidemic.

\section{IT IS A LONG HAUL FROM 2010 TO 2025}

There are major gaps in knowledge to be filled in the field of viral respiratory infections and influenza in particular. Little is known about contagion mechanisms or the contribution played by touch contamination (i.e., fomites such as flat surfaces, door handles, etc.). There is a lack of rigorous evaluation of the efficacy of surgical masks worn by contagious persons or of alcohol-based gel hand sanitizer. The appropriateness, timing, duration and social and economic consequences of closing schools have not been evaluated. There is little information on the "altruistic" efficacy of vaccinating health personnel ${ }^{65,66}$; only a few trials have been carried out in retirement homes, not all of which were conclusive. ${ }^{67}$

No trial vaccination has, thus far, been attempted as a barrier against any seasonal influenza epidemic. ${ }^{68,69}$ The link between Guillain-Barré syndrome and vaccination is still in dispute, not to mention the quantification of the risk. ${ }^{70,71}$ The efficacy of antiviral drugs for serious cases and for reducing mortality has not been satisfactorily evaluated, nor has their mass use outside theoretical computer simulations. We do not know what impact treatment with preventive doses as post-exposure prophylaxis will have on 
the emergence of resistant strains. The natural history of influenza is still largely unknown. What are the determinants of clinical forms of the influenza syndrome? Little is known about the case mix or the distribution of clinical forms related to the infection. Little is known about the viral variability. ${ }^{10}$ Even less is known about the determinants of the severity of the influenza. Why does Acute Respiratory Distress Syndrome (ARDS) occur? Why does secondary invasive bacterial infection occur? Why is 90 percent of mortality due to seasonal influenza not identified by doctors (only 10 percent of influenza-related deaths are recorded as being caused (either primary or secondary) by influenza in death certificates)? We know nothing about the physiopathological mechanisms of this high mortality nor the efficacy of antiviral drugs for preventing or even treating these severe cases nor how and when antibiotics can be used in the treatment of complications, or bacterial vaccines in their prevention. Respiratory complications of influenza are the major causes of death both in seasonal and pandemic situations; medical facilities are confronted with ARDS. Secondary bacterial invasive infections may mask the primary influenza infection, and thus may not be identified medically. It is estimated that influenza is recorded as either the primary or secondary cause of death in only 10 percent of influenza related deaths. ${ }^{72-74}$

However, the route is also technological and political. Between 2010 and 2025, the major international observatories mentioned above may at last be set up to monitor the emergence of epidemics. They will be designed as a grid covering the whole of the world in the same way as meteorological stations and will be linked to a World Health Organisation that is more reactive, better informed and equipped with better resources.

\section{THE ROLE OF THE WHO}

Governments set great store through vaccination against pandemic influenza for public health reasons as well as for economic reasons. "Much is riding on the success of vaccination - as well as preventing illness and saving lives, some economists say that curbing the pandemic could prevent hefty financial losses." 75 Beyond this is the competition between the various powers for world leadership in the fight against pandemic risk - whoever successfully manages both the health crisis and the economic crisis will prevail. There is, however, another question, of even greater importance.

On the $17^{\text {th }}$ of September, 2009, the United Nations sent Health Ministries worldwide the conclusions of a report (ordered in July by the Secretary General) in the form of a cry for help. Eighty-five of the poorest countries 
in the world could not afford vaccines. "The virus could destroy a burgeoning economy or democracy," claimed the WHO, in the purest veins of Thucydides' paradigm. ${ }^{76}$ In the context of the concomitant financial crisis and recession, the WHO is well aware that obtaining the support of the rich countries may well prove to be very difficult.

The WHO rather lost its way during the 1980s with respect to influenza policy. Since 1995, it has rebuilt its monitoring and alert systems: the new Division of Communicable Diseases was created (1996), the Global Outbreak Alert and Response Network was set up (2001) and new international health regulations were issued in 2005 (came into effect in 2007) which relieve governments of their veto on epidemiological information. This new era - a "sort of second birth"77- was demonstrated by its bold strategy deployed during the SARS epidemic when a global alert ${ }^{78}$ without prior agreement from governments, was issued on the $12^{\text {th }}$ of March, 2003, along with a travel advisory on the $24^{\text {th }}$ of April, advising against travel to Beijing and the Shanxi province in China, as well as Toronto, Canada, while there was open confrontation with the Chinese government regarding the statistics and the progress of the epidemic.

Today, all governments swear to maintain the closest cooperation possible with the WHO. Did Dr Margaret Chang take the trouble to specify in her statement of the $11^{\text {th }}$ of June, 2009 that the WHO does not recommend any uniform scheme and that the order of the day is "adaptation to the local situation"? ${ }^{17}$ Even so, the old attitudes reappear. "What really matters is what individual countries are doing on the ground to tackle the disease and that is not dictated by WHO, but determined by national governments." ${ }^{\text {"79 }}$

The slightest attempt by the WHO to take technical control of operations is immediately censured: down with "world government"!

Controversial allegations that some WHO advisors have conflicts of interest have clouded the public's perception of the H1N1 pandemic of $2009 .{ }^{80,81}$ This may partially explain low rates of uptake of the vaccine in many countries. These issues will undoubtedly affect future policy formulation and public attitudes in threatened pandemic situations. Seasonal flu vaccine for risk groups has been accepted as a basic preventive health measure in many health systems, e.g., UK. The H1N1 vaccination rate is estimated by CDC at 75 million or close to 25 percent of the US population, well below figures of 114 million for seasonal flu immunization. ${ }^{82}$

The pharmaceutical industry also has its own strategy which is different from that of the WHO. The WHO asked manufacturers to donate about 10 percent of their vaccine production to low-income countries (400 million doses out of 5 billion). Six manufacturers out of thirty agreed. GlaxoSmithKline 
and Sanofi-Aventis said that they would donate 150 million doses. Novartis said they would consider discounts if necessary but did not offer to provide the vaccine free of charge, as a rebuff to Ban Ki-Moon, who, on the $19^{\text {th }}$ of May, called on the directors of the pharmaceutical groups for "world solidarity," as well as to Margaret Chan who made the same plea two weeks later.

The day after the United Nations press release, nine countries solemnly promised to release 10 percent of their stock of vaccines to the WHO.$^{83}$ Will this be enough? Will this come in due time? The world's vaccine production capacity will be insufficient in any case, as the WHO well knows. The WHO is gambling high on the political question of equity. This will decide the leadership stakes during the current pandemic and in the future.

\section{SUMMARY AND CONCLUSIONS}

The 1918 Swine flu pandemic has left an important legacy, much like the Black Plague did four centuries earlier. The folk and political memory of 1918 influenced modern virological and epidemiological thinking when facing potentially robust if not disastrous epidemics during the latter part of the $20^{\text {th }}$ century. The 1976 non-pandemic which caused a national mobilisation in the US with mass immunization resulted in a serious reduction in credibility of the public health community and governmental action in epidemic control.

Subsequent influenza pandemics energised national governments to review their public health structure and laboratory support, and encouraged international agencies to prepare for possible future influenza pandemics, especially in their capacity for rapid production of vaccines, in addition to the seasonal influenza vaccines now accepted as essential to normal public health practice. When in May of 2009, the H1N1 influenza appeared and was declared to have pandemic potential, WHO and national governments globally prepared to address the worst case scenarios, taking into account millions of possible cases and deaths. In June of 2010, WHO reported that the global H1N1 pandemic included some 18 thousand deaths and the virus is still circulating, though at much reduced levels compared to those in the fall of 2009. Enormous stockpiles of vaccine and Tamiflu went largely unused with poor levels of acceptance in the general public and even among health care providers. These stocks were then donated or sold inexpensively to developing countries.

The role of international cooperation and that of WHO in this pandemic needs to be re-examined. The lack of public response to available 
immunizations points to an important credibility issue, and the sharing of available vaccine with developing countries requires international attention. It is likely that, after 2010, the experience of H1N1 pandemic influenza will be passed through a fine sieve throughout the world. Although it is difficult to anticipate the conclusions of this analysis at this stage, it is probable that in the future, we will want to be better prepared for the emergence of such epidemics. We will not focus solely on the particularly virulent strains such as $\mathrm{H} 5 \mathrm{~N} 1$, rather taking measures against a subtype $\mathrm{H} 1 \mathrm{~N} 1$ pandemic influenza that is predominantly benign (apart from a fairly low proportion of serious cases) but nevertheless significant at the country scale and able to affect health, society and the global economy.

\section{Acknowledgments:}

The authors wish to thank Beverley Tebby for her help in translation. They are also grateful to Ted Tulchinsky and the referees for their help, advice and patience.

Conflicts of interest: None declared.

\section{REFERENCES}

1. World Health Organization. Pandemic (H1N1) 2009 - update 105. Available from URL: http://www.who.int/csr/don/2010_06_18/en/ (Accessed 19 June, 2010).

2. Barry JM. The great influenza: the epic story of the deadliest plague in history. New York: Penguin Viking; 2004.

3. Taubenberger JK, Morens DM. 1918 influenza: the mother of all epidemics. Emerg Infect Dis. 2006;12:15-22. Available from URL: http://www.cdc.gov/ ncidod/EID/vol12no01/05-0979.htm (Accessed 19 June, 2010).

4. Dowdle WR. Pandemic influenza: confronting a re-emergent threat. The 1976 experience. J Infect Dis 1997;176 Suppl-1:S69-72. Available from URL: http://www.ncbi.nlm.nih.gov/pubmed/9240699 (Accessed 18 June, 2010).

5. Fouchier RAM, Kuiken T, Schutten M, van Amerongen G, van Doornum GJJ, van den Hoogen BG et al. Aetiology: Koch's postulates fulfilled for SARS virus. Nature 2003:423:240. Available from URL: http://www.nature.com/ nature/journal/v423/n6937/pdf/423240a.pdf (Accessed 18 June, 2010).

6. World Health Organization. Severe Acute Respiratory Syndrome (SARS) multi-country outbreak. Update 31, 16 April 2003. Available from URL: http://www.who.int/csr/don/2003_04_16/en/ (Accessed 18 June, 2010).

7. World Health Organization. Cumulative number of confirmed human cases of Avian influenza A/(H5N1) reported to WHO. (24 September, 2009). Available from URL: http://www.who.int/csr/disease/avian_influenza/country/cases_ table_2009_09_24/en/index.html (Accessed 18 June, 2010). 
8. Bishop JF, Murnane MP, Owen R. Australia's winter with the 2009 pandemic influenza A (H1N1) virus. N Engl J Med. 2009;361:2591-4. Available from URL: http://content.nejm.org/cgi/reprint/NEJMp0910445.pdf (Accessed 18 June, 2010).

9. de Lamballerie X. Personal communication, June, 2010.

10. Centers for Disease Control and Prevention. 2009 H1N1 early outbreak and disease characteristics. Available from URL: http://www.cdc.gov/h1n1flu/ surveillanceqa.htm (Updated 27 October, 2009 and accessed 18 June, 2010).

11. Paris correspondents. First worldwide profile of swine flu victims. Herald Sun (Victoria, Australia). August 26, 2009. Available from URL: http://www. heraldsun.com.au (Accessed 18 June, 2010).

12. Ross T, Zimmer S, Burke D, Crevar C, Carter D, Stark J, et al. Seroprevalence following the second wave of pandemic 2009 H1N1 influenza. PLoS Curr Influenza. 24 Feb, 2010: RRN1148 Available from URL: http://www.ncbi. nlm.nih.gov/pubmed/20191082 (Accessed 18 June, 2010).

13. Flahault A. First estimation of direct H1N1pdm virulence: From reported non consolidated data from Mauritius and New Caledonia. PLoS Curr Influenza. 2009 Aug 23:RRN1010. Available from URL: http://www.ncbi.nlm.nih.gov/ pubmed/20020674 (Accessed 18 June, 2010).

14. Centers for Disease Control and Prevention. Bacterial coinfections in lung tissue specimens from fatal cases of 2009 pandemic Influenza A (H1N1) United States, May-August 2009. MMWR Morb Mort Wkly Rep. 2009; 58:1-4. (early release) Available from URL: http://www.cdc.gov/mmwr/pdf/ wk/mm58e0929.pdf (Accessed 18 June, 2010).

15. The ANZIC Influenza Investigators. Critical care services and 2009 H1N1 influenza in Australia and New Zealand. N Engl J Med. 2009;361:1925-34. Available from URL: http://content.nejm.org/cgi/content/full/361/20/1925 (Accessed 18 June, 2010).

16. Reed C, Angulo FJ, Swerdlow DL, Lipsitch M, Meltzer MI, Jernigan D, Finelli L. Estimates of the prevalence of pandemic (H1N1) 2009, United States, April-July 2009. Emerg Infect Dis. 2009;15: December. Available from URL: http://www.cdc.gov/eid/content/15/12/pdfs/2004.pdf (Accessed 18 June, 2010).

17. World Health Organization. Transcript of statement by Margaret Chan, DirectorGeneral of the World Health Organization. 11 June, 2009. Available from URL: http://www.who.int/mediacentre/influenzaAH1N1_presstranscript_ 20090611.pdf (Accessed 18 June, 2010).

18. Centers for Disease Control and Prevention. Centers for Disease Control and Prevention. 2009 H1N1 flu: situation update. Available from URL: http:// www.cdc.gov/h1n1flu/update.htm (Accessed 20 June, 2010).

19. Centers for Disease Control and Prevention. CDC Estimates of 2009 H1N1 influenza cases, hospitalizations, and deaths in the United States, AprilDecember 12, 2009. Available from URL: http://www.cdc.gov/h1n1flu/ estimates/April_December_12.htm\#Table (Accessed 18 June, 2010). 
20. Boussard E, Flahault A, Vibert JF, Valleron AJ. Sentiweb: French communicable disease surveillance on the world wide web. BMJ. 1996;313:1381-4. Available from URL: http://www.bmj.com/cgi/content/full/313/7069/1381 (Accessed 18 June, 2010).

21. Sentinelles. Réseau Sentinelles France (weekly epidemiologic record for France). Available from URL : http://www.sentiweb.org/ (Accessed 18 June, 2010).

22. Paget J, Marquet R, Meijer A. van der Velden K. Influenza activity in Europe during eight seasons (1999-2007): an evaluation of the indicators used to measure activity and assessment of the timing, length and course of peak activity (spread) across Europe. BMC Infect Dis. 2007;7:141 Available from URL: http://www.ncbi.nlm.nih.gov/pubmed/18047685 (Accessed 18 June, 2010).

23. Viboud C, Boëlle PY, Pakdaman K, Carrat F, Valleron AJ, Flahault A. Influenza epidemics in the United States, France, and Australia, 1972-1997. Emerg Infect Dis. 2004;10:32-9. Available from URL: http://www.ncbi.nlm.nih. gov/pubmed/15078594 (Accessed 18 June, 2010).

24. Lemaitre M, Carrat F. Comparative age distribution of influenza morbidity and mortality during seasonal influenza epidemics and the $2009 \mathrm{H} 1 \mathrm{~N} 1$ pandemic. BMC Infectious Diseases. 2010;10:162 doi:10.1186/1471-2334-10-162. Available from URL: http://www.biomedcentral.com/content/pdf/1471-233410-162.pdf (Accessed 20 June, 2010).

25. Thompson WW, Shay DK, Weintraub E, Brammer L, Cox N, Anderson LJ, et al.Mortality associated with influenza and respiratory syncytial virus in the United States. JAMA. 2003;289:179-86. Available from URL: http://jama. ama-assn.org/cgi/content/abstract/289/2/179 (Accessed 19 June, 2010).

26. Centers for Disease Control and Prevention. Seasonal influenza (flu); Estimating deaths from seasonal influenza in the United States. Available from URL: http://www.cdc.gov/flu/about/disease/us_flu-related_deaths.htm (Accessed 19 June, 2010).

27. Carrat F, Valleron AJ. Influenza mortality among the elderly in France, 198090: how many deaths may have been avoided through vaccination? J Epidemiol Community Health. 1995;49:419-25. Available from URL: http:// www.ncbi.nlm.nih.gov/pubmed/7650467 (Accessed 18 June, 2010).

28. Reichert TA, Sugaya N, Fedson DS, Glezen WP, Simonsen L, Tashiro M. The Japanese experience with vaccinating schoolchildren against influenza. New Engl J Med. 2001; 344:889-96. Available from URL: http://content.nejm.org/ cgi/content/short/344/12/889 (Accessed 18 June, 2010).

29. Centers for Disease Control. Key facts about seasonal flu vaccine. Available from URL: http://www.cdc.gov/Flu/protect/keyfacts.htm (Posted 16 October, 2009 and accessed 18 June, 2010).

30. Skowronski DM, Astell C, Brunham RC, Low DE, Petric M, Roper RL, et al. Severe acute respiratory syndrome (SARS): A year in review. Annu Rev 
Med. 2005;56:357-81. Available from URL: http://www.ncbi.nlm.nih.gov/ sites/pubmed (Accessed 18 June, 2010).

31. Morens DM, Taubenberger JK. Understanding influenza backward. JAMA. 2009;302:679-80. Available from URL: http://www.ncbi.nlm.nih.gov/sites/ pubmed (Accessed 18 June, 2010).

32. Taubenberger JK. Genetic characterisation of the 1918 'Spanish' influenza virus. In Phillips H, Killingray D, editors. The Spanish influenza pandemic of 1918-19. New perspectives. London: Routledge; $2003: 39-46$, p. 43. Available from URL: http://www.questia.com/PM.qst?a=o\&d=104243843 (Accessed 18 June, 2010).

33. Ohadike DC. Diffusion and physiological responses to influenza pandemic of 1918-1919 in Nigeria. Social Science and Medicine. 1991;32:1393-9. Available from URL: http://www.sciencedirect.com/ (Accessed 18 June, 2010).

34. Delater Dr. La grippe dans la nation armée de 1918 à 1921. Revue d'hygiene. 1923;45:409-634.

35. Oxford JS, Sefton A, Jackson R, Innes W, Daniels RS, Johnson NPAS. World War I may have allowed the emergence of "Spanish" influenza. Lancet Infect Dis. 2002;2:111-4. Available from URL: http://www.ncbi.nlm.nih.gov/pubmed/ 11901642 (Accessed 18 June, 2010).

36. Yin S. Avian Flu and Influenza pandemics. Washington: Population Reference Bureau;2006. Available from URL: http://www.prb.org/Articles/2006/Avian FluandInfluenzaPandemics.aspx (Accessed 18 June, 2010).

37. Defressine and Violle, La prophylaxie et le traitement de la grippe, C. R. hébdo, séances Acad. Sci., 1918; 167: 503; and J. Castaigne, Chronique, J. Méd. franç., 1919; 8: 11-14. In: Phillips H, Killingray D. The Spanish influenza pandemic of 1918-19: new perspectives. London: Routledge; 2003.

38. Johnson NPAS. The overshadowed killer. Influenza in Britain in 1918-19. In: Phillips H, Killingray D, editors. The Spanish influenza pandemic of 191819: new perspectives. London: Routledge; 2003:132-55, pp.137-38.

39. Becker JJ. La grippe espagnole, memoire d'une guerre. Liberation. 9 October, 2009. Available from URL: http://www.liberation.fr/societe/0101596047-lagrippe-espagnole-memoire-d-une-guerre (Accessed 18 June, 2010).

40. Taubenberger JK, Morens DM. 1918 influenza: the mother of all pandemics, Emerg Infect Dis. 2006;12:15-22. Available from URL: http://www.cdc.gov/ ncidod/eid/vol12no01/pdfs/05-0979.pdf (Accessed 18 June, 2010).

41. Préfecture de la Seine. Épidémie de grippe à Paris, 30 juin 1918-26 avril 1919. Paris: Imprimerie des Beaux-Arts; s.d. [1919]. (Service de la statistique municipale; $2^{\mathrm{e}}$ année, no. 2).

42. Ministére de la Guerre. Statistiques médicales. I - Données statistiques relatives à la guerre 1914-1918, Paris, 1922.

43. Phillips H, Killingray D, editors. The Spanish influenza pandemic of 1918-19: new perspectives. London: Routledge; 2003.

44. Patterson KD. Pandemic influenza, 1700-1900: a study in historical epidemiology. Totowa, NJ: Rowman and Littlefield; 1986. 
45. Hays JN. Epidemics and pandemics: Their impact on human history. Santa Barbara (CA): ABC-CLIO Inc; 2005:88-89.

46. Thucydides, The Peloponesian War (circa 400 BC), translated by Crawley R, edited by Wick TE, New York: Modern Library.1982.

47. Burrow J. A history of histories. Epics, chronicles, romances \& inquiries from Herodotus \& Thucydides to the twentieth century. London: Penguin Books; 2009.

48. Kilbourne ED. Influenza pandemics of the 20th century. Emerg Infect Dis. 2006;12:9-14. Available from URL: http://www.ncbi.nlm.nih.gov/pubmed/ 16494710 (Accessed 19 June, 2010).

49. Viboud C, Grais RF, Lafont BA, Miller MA, Simonsen L. Multinational impact of the 1968 Hong Kong influenza pandemic: evidence for a smoldering pandemic, J. Infect. Dis. 2005; 192: 233-48. Available from URL: http:// www.ncbi.nlm.nih.gov/pubmed/15962218 (Accessed 10 June, 2010).

50. Gensheimer KF, Fukuda K, Brammer L, Cox N, Patriarca P, Strikas RA. Preparing for pandemic influenza: the need for enhanced surveillance. Emerg Infect Dis. 1999;5:297-9. Available from URL: http://www.ncbi.nlm.nih. gov/pubmed/10221887 (Accessed 10 June, 2010).

51. Valleron AJ, Boumendil A. Epidemiology and heat waves: analysis of the 2003 episode in France. C R Biol. 2004;327:1125-41. Available from URL: http:// www.ncbi.nlm.nih.gov/sites/pubmed (Accessed 19 June 2010).

52. Boffey PM. Swine flu vaccination campaign: the scientific controversy mounts. Science. 1976;193:559-63. Available from URL: http://www.ncbi.nlm.nih. gov/pubmed/17759577 (Accessed 19 June, 2010).

53. Stöhr K, Esveld M. Public health: Will vaccines be available for the next influenza pandemic? Science. 2004;306, 24 2195=6. Available from URL: http://www.ncbi.nlm.nih.gov/pubmed/15618505 (Accessed 19 June, 2010).

54. Schwarzinger M, Flicoteaux R, Cortarenoda S, Obadia Y, Moatti JP. Low acceptability of A/H1N1 pandemic vaccination in French adult population. Did public health policy fuel public dissonance? PLoS One. April 2010; 5:e1099. Available from URL: http://www.ncbi.nlm.nih.gov/pubmed/ 20421908 (Accessed 19 June, 2010).

55. Setbon M, Raude J. Factors in Vaccination intention against the pandemic influenza A (H1N1). Eur J Publ Health. 5 May, 2010 [e pub ahead of print] Available from URL: http://www.ncbi.nlm.nih.gov/pubmed/ 20444821?dopt =Abstract (Accessed 19 June, 2010).

56. Valéry P. Regards sur le monde actuel (1931), in Oeuvres, ed. J. Hytier, t. II, Paris: Gallimard (Pléiade), 1960, p. 917.

57. Gaydos JC, Top FH, Hodder RA, Russell PK. Swine influenza A outbreak, Fort Dix, New Jersey, 1976. Emerg Infect Dis 2006;12:23-8. Available from URL: http://www.ncbi.nlm.nih.gov/pubmed/16494712 (Accessed 19 June, 2010).

58. Krause R. The swine flu episode and the fog of epidemics. Emerg Infect Dis. 2006;12:40-3. Available from URL: http://www.ncbi.nlm.nih.gov/pubmed/ 16494715 (Accessed 19 June, 2010). 
59. Sencer DJ, Millar JD. Reflections on the 1976 swine flu vaccination program. Emerg Infect Dis 2006;12:29-33. Available from URL: http://www.ncbi.nlm. nih.gov/pubmed/16494713 (Accessed 19 June, 2010).

60. Neustadt RE, Fineberg HV. The epidemic that never was: policy-making in the swine flu scare. New York: Vintage Books; 1983.

61. Dowdle WR. Influenza pandemic periodicity, virus recycling, and the art of risk assessment. Emerg Infect Dis. 2006;12:34-9. Available from URL: http:// www.ncbi.nlm.nih.gov/pubmed/16494714 (Accessed 18 June, 2010).

62. Crosby AW. Epidemic and peace, 1918. Westport: Greenwood Press; 1976.

63. Dowdle WR. The 1976 experience. J Infect Dis. 1997;176(suppl 1):S69-72. Available from URL: http://www.journals.uchicago.edu/doi/abs/10.1086/ 514180 (Accessed 19 June, 2010).

64. Tulchinsky TH. Personal communication, April, 2010

65. Thomas RE, Jefferson T, Lasserson TJ. Influenza vaccination for healthcare workers who work with the elderly. The Cochrane Collaboration, John Wiley \& Sons Limited; 2010. Available from URL: http://www.thecochranelibrary. com/SpringboardWebApp/userfiles/ccoch/file/CD005187.pdf (Accessed 20 June, 2010).

66. Hayward AC, Harling R, Wetten S, Johnson AM, Munro S, Smedley J, et al. Effectiveness of an influenza vaccine programme for care home staff to prevent death, morbidity and health service use among residents: cluster randomized controlled trial. BMJ. 2006;333:1241. Available from URL: http://www.bmj. com/cgi/content/abstract/333/7581/1241 (Accessed 20 June, 2010).

67. Lemaitre M, Meret T, Rothan-Tondeur M, Belmin J, Lejonc JL, Luquel L, et al. Effect of influenza vaccination of nursing home staff on mortality of residents: a cluster-randomized trial. J Am Geriatr Soc. 2009;57:1580-6. Available from URL: http://www3.interscience.wiley.com/journal/122538809/abstract? CRETRY=1\&SRETRY=0 (Accessed 20 June, 2010).

68. Centers for Disease Control and Prevention. Seasonal influenza vaccination health resources for professionals: 2009-10 recommendations of the Advisory Committee on Immunization practices (ACIP). Available from URL: http:// 198.246.98.21/flu/professionals/vaccination/index.htm (Accessed 20 June, 2010).

69. La Montagne JR, Noble GR, Quinnan GV, Curlin GT, Blackwelder WC, Smith JI, et al. Summary of clinical trials of inactivated vaccine - 1978. Rev. Infect. Dis. 1983;5:723-36. Available from URL: http://www.ncbi.nlm.nih.gov/pubmed/ 6353529 (Accessed 20 June, 2010).

70. Stowe J, Andrews N, Wise L, Miller E. Investigation of the temporal association of Guillain-Barré syndrome with influenza vaccine and influenza-like illness using the United Kingdom general practice research database. Am J Epidemiol. 2009;169:382-8. Available from URL: http://aje.oxfordjournals.org/cgi/ content/full/kwn310 (Accessed 20 June, 2010).

71. Hurwitz ES, SchonbergerLB, Nelson DB, Hollman RC. Guillain-Barre syndrome and the 1978-1979 influenza vaccine. N Engl J Med. 1981;304:1557-61. 
Available from URL: http://content.nejm.org/cgi/content/abstract/304/26/ 1557 (Accessed 20 June, 2010).

72. Patel M, Dennis A, Flutter C, Khan Z. Pandemic (H1N1) 2009 influenza. Br J Anaesth. 2010;104:128-42. Available from URL: http://www.ncbi.nlm.nih. gov/pubmed/20053625 (Accessed 20 June 2010).

73. Kumar A, Zarychanski R, Pinto R, Cook DJ, Marshall J, Lacraoix, et al. Critically ill patients with 2009 influenza A(H1N1) infection in Canada. JAMA. 2009;302:1872-9. Available from URL: http://www.ncbi.nlm.nih.gov/sites/ pubmed (Accessed 20 June, 2009).

74. Centers for Disease Control and Prevention. Seasonal influenza (flu); Estimating deaths from seasonal influenza in the United States. Available from URL: http:// www.cdc.gov/flu/about/disease/us_flu-related_deaths.htm (Accessed 19 June, 2010).

75. Shetty P. H1N1 vaccine could staunch further financial loss. Lancet Infect Dis. 2009;9:592. Available from URL: http://www.thelancet.com/journals/laninf/ article/PIIS1473-3099(09)70243-9/fulltext (Accessed 20 June, 2010).

76. Syal R. Swine flu ‘could kill millions unless rich nations give $£ 900 \mathrm{~m}$ '. The Observer. 20 September, 2009. Available from URL: http://www.guardian. co.uk/world/2009/sep/20/swine-flu-costs-un-report (Accessed 20 June, 2010).

77. Murard L. L'organisation internationale de la lutte contre les épidémies (18512005). In: Flahault A, Zylberman P. Editors. Des épidémies et des hommes. Paris; De La Martinière; 2008. (pp. 83-92).

78. World Health Organization. WHO extends its SARS-related travel advice to Beijing and Shanxi province in China and to Toronto, Canada. Available from URL: http://www.who.int/ (Accessed 20 June, 2010).

79. Triggle N. What comes next in the flu fight? BBC News. 11 June, 2009. Available from URL: http://news.bbc.co.uk/2/hi/health/8093482.stm (Accessed 20 June, 2010).

80. Godlee F. Editorial: Conflicts of interest and pandemic flu. BMJ. 2010;340:c2947. Available from URL: http://www.bmj.com/cgi/content/full/340/jun03_4/ c2947 (Accessed 20 June, 2010).

81. World Health Organization. WHO Director General's letter to BMJ editors. 8 June, 2010. Available from URL: http://www.who.int/mediacentre/news/ statements/2010/letter_bmj_20100608/en/index.html (Accessed 20 June, 2010).

82. Roos R. US H1N1 vaccine uptake estimated at 75 million. CIDRAP. Available from URL: http://www.cidrap.umn.edu/cidrap/content/influenza/swineflu/ news/feb0410vac.html (Accessed 20 June, 2010).

83. Public Health Agency of Canada. Government of Canada announces significant contribution to WHO global pandemic relief efforts. News release. 28 January, 2010. Available from URL: http://www.phac-aspc.gc.ca/media/nr-rp/ 2010/ 2010_0128-eng.php (Accessed 20 June, 2010). 